\title{
Unfolding The Possibility to Develop Share-waqf in Indonesia Through The Concepts, Opportunities \& Challenges
}

\author{
Aldi Khusmufa Nur Iman', Faridatun Najiyah², Munji \\ Asshiddiqi $^{3}$ \\ ${ }^{1}$ UIN Sunan Ampel Surabaya \\ ${ }^{2}$ STEI Permata Bojonegoro \\ ${ }^{3}$ The University of Queensland Australia \\ email: aldikhusmufa@gmail.com,najiyahfaridatun@gmail.com, \\ munas.sidiq@gmail.com
}

\begin{abstract}
Indonesia is a country with the largest Muslim population in the world. The potential of Islamic financial instruments for the welfare of the people grows in society, one of which is cash waqf and shares. Most Islamic scholars allow cash and shares to be used as objects of waqf. Both cash and stock endowments can be implemented into two models. Cash waqf can be implemented as mutual funds or converted into other fixed assets. Meanwhile, the implementation of share waqf can be done through corporate waqf and individual share waqf. Individual share waqf is applied with two models, namely waqf from the profit of shares and waqf in the form of per-lot Sharia shares. The purpose of this study is to determine the concepts, opportunities and challenges of share waqf in Indonesia. Based on the research, it was found that share waqf has a great opportunity in Indonesia, considering that the majority of the population is Muslim. However, the implementation of the share waqf program in Indonesia in the future face various challenges that must be resolved in order for the share waqf to develop in Indonesia.
\end{abstract}

Keywords: Waqf, Cash Waqf, Share Waqf. 


\section{INTRODUCTION}

From the time of the Prophet to the present, waqf has experienced rapid development. Waqf is donating wealth for the benefit of the people. Waqf assets cannot be reduced in value, cannot be sold and cannot be inherited. Allah has promised a large reward and multiple benefits for anyone who donates his wealth in the way of Allah.

In the last few years, the discussion about cash waqf or productive waqf has become a topic of conversation. Waqf, whose object was initially limited to fixed assets such as land and buildings, began to develop based on the principle of the benefits to be distributed through waqf and to maximize the benefits felt by the recipient so that new waqf objects emerged in the form of movable objects such as cash, share endowments and waqf securities.

During its development, there was the implementation of cash waqf as was done in the Ottoman era meaning that cash waqf has been known for a long time and the potential for cash waqf is enormous in improving social, economic, educational services, especially in the religious field. Cash waqf is relatively new in Indonesia; however, this has long been studied and developed in other countries such as Egypt, Turkey and Bangladesh (Rozalinda, 2017). Money as a micro payment instrument can make the payment process faster, easier, efficient, and safer (Febriandika and Hakimi, 2020).

The introduction of other recent waqf innovations in Indonesia such as sukuk waqf, stock waqf, and other waqf is currently trending, one of which is by holding seminars on campuses in collaboration with Badan Wakaf Indonesia (BWI) as an effort to introduce these products. Waqf institutions have rights and obligations that must be fulfilled (Febriandika, 2020).

Indonesia is one of the potential sources of productive waqf, considering that this country has a predominantly Muslim population composition and has a total population of 207.6 million (Febriandika et al., 2020; World Bank, 2019). With the implementation of zakat and waqf institutions correctly and adequately, it is expected that the difficulties and suffering of the 
poor can be reduced (Najiyah and Febriandika, 2019). Besides, based on the growth of stock investors on the Indonesia Stock Exchange (IDX), as of November 28, 2019, the IDX again set a new record in 2019, the number of stock investors on the IDX has reached 1,089,987 SID or an increase of 27.8 per cent when compared to last year. This figure exceeds the record for achieving the number of new investors recorded in 2018 of 852,240 SID (IDX, 2019).

Based on the background described above, the formulation of the problem taken is What are the Concepts, Opportunities and Challenges of Share Waqf in Indonesia?

\section{LITERATURE REVIEW Share Waqf}

Waqf is a legal act of wakif to separate and/or hand over part of his property to be used forever or for a certain period following his interests for worship and/or general welfare according to Sharia.

Waqf has a massive potential to be developed according to the needs of the times as a significant force that can drive the wheels of community welfare. However, most of the waqf laws are established based on the results ijtihad, especially in fields related to types of waqf, requirements, management aspects and allotments with the qiyas method and maslahat al-mursalah. This case occurs due to the lack of waqf laws stipulated by al-Qur'an and al-Hadith, so the recommendation regarding waqf is placed in the area of ijtihadi and not ta'abbudi. However, the little verses of the Qur'an and the Prophet's hadiths remained the guidance of jurists (Hadi, Fikih Muamalah Kontemporer, 2017).

The development of waqf from time to time is caused by the property (property) of waqf. Waqf objects are the object of ijtihad because there are objects which are not moving, and there are moving objects such as money and services. The difference in the situation and condition of the fiqh scholars in understanding al-Qur'an and hadith also makes the stipulation of the conditions for objects that can be donated can be different for each ulama (Muzarie, 2010). Waqf is an Islamic charity in the form of fixed 
assets. Along with the times, waqf innovation is becoming increasingly modern. The large population of Indonesian Muslims is very potential for the development of waqf. Therefore, currently, Indonesia is trying to make innovations related to waqf in order to attract the interest of modern society to like and like waqf, one of which is by introducing movable object waqf.

The types of waqf assets in Law Number 41 concerning waqf consist of immovable objects and movable objects. Movable objects are objects that cannot be consumed, such as money, precious metals, securities, vehicles, intellectual property rights, lease rights, and other movable objects under Sharia provisions and statutory regulations. Moreover, one of the movable objects that can be donated according to Law No. 41 Article 21 is shares (Law No. 41 of 2004).

\section{Sharia Share}

Sharia shares are stocks that do not conflict with Sharia principles because shares are proof of investment from investors to companies, which then the investors will get a dividend. However, not all shares can be directly categorized as Sharia shares; they must go through a screening of Sharia shares by the financial services authority:

a. Business Screening

Not carrying out business activities, including the following: Gambling and the like, prohibited trading, ribawi financial services, trading risks that contain an element of uncertainty (gharar) and/or gambling (maisir), Production and distribution of illicit goods, bad morals or harm bribery transactions.

b. Do not conduct transactions that are contrary to Sharia principles in the capital market.

c. Financial screening.

Total interest-based debt to total assets is not more than $45 \%$ non-halal income compared to total income, not more than $10 \%$. 
Issuers / Public Companies that meet these criteria have their shares listed in the Sharia Securities List (DES) issued by the Financial Services Authority (POJK Number 15: 2015).

The Indonesian capital market recognizes two types of Sharia shares. That is:

1. Shares declared to meet the selection criteria for Sharia shares based on OJK regulation no. II.K.1 concerning the issuance of the Sharia Securities List.

2. Shares listed as Sharia shares by the issuer or Sharia public company based on OJK regulation no. 17 / POJK.04 / 2015. All Sharia shares contained in the Indonesian Sharia Capital Market, whether listed on the IDX or not, are included in the list of Sharia Securities (DES) issued by the OJK periodically, every May and November (Modul SPM, 2018).

3. Waqf Shares: Sharia Perspective

Fatwa No. 80 DSN-MUI / III / 2011 also affirms the ability to trade securities but must be accompanied by full vigilance. Concerning waqf through the media of shares, Indonesia's waqf law states that shares are classified as movable objects that can be donated. Meanwhile, the majority of scholars, especially from the Maliki, Syaf'i, and Hambali schools of thought allow the implementation of wakaf for moving objects. Therefore, it can be concluded that the law of stock waqf is equated with the law of other movable property waqfs, which is permissible (DSN-MUI, 2011).

\section{METHODS}

This research uses a qualitative approach. By using the library research method, data obtained from secondary data in the form of books, articles, and processed data from other parties or publication data such as data on the Indonesian stock exchange publications, publications from financial services authorities and those related to this research. 


\section{RESULT \& DISCUSSION Share Waqf Model and Concept}

In practice, the concept of share waqf is different from immovable assets such as land and building waqf. This regard affected by the form of shares cannot be utilized directly and must be fulfilled in terms of immutability. Therefore, in its application, a particular model is needed, so that shares can be used as waqf assets (Paksi, Manzilati, \& Ekawaty, 2018).

Share waqf, according to its substance, can be categorized almost the same as cash waqf, because it is included in the definition of money as securities (Majelis Ulama Indonesia, 2002). However, the difference is in the management model. Stock waqf is categorized as one type of productive waqf derived from the management of sharia shares which are converted into waqf and used for productive or social purposes, in this case, sharia investors are actively involved in becoming waqf actors (Wakaf Al Azhar, 2020).

The Indonesia Stock Exchange (IDX) has launched two models for the application of stock waqf, namely waqf which comes from the profits of stock investors and second, waqf which makes Islamic shares the object of waqf (Hogan, 2016). In the application of the first model, the share investor's profit percentage is used as a source of waqf, in other words, the proceeds from the sale of Islamic shares in the form of a margin or profit cut directly. The process of cutting profits involves an exchange member institution that has a Sharia Online Trading System (SOTS). Then the profits that will be donated are paid to the waqf management institution (Nadzir), which has previously collaborated with the SOTS exchange member institution. Later, the waqf management institution (Nadzir) will convert these profits into productive assets or social assets according to the waqf program they have, such as building mosques or schools. The following is the scheme for implementing the first model share waqf: 


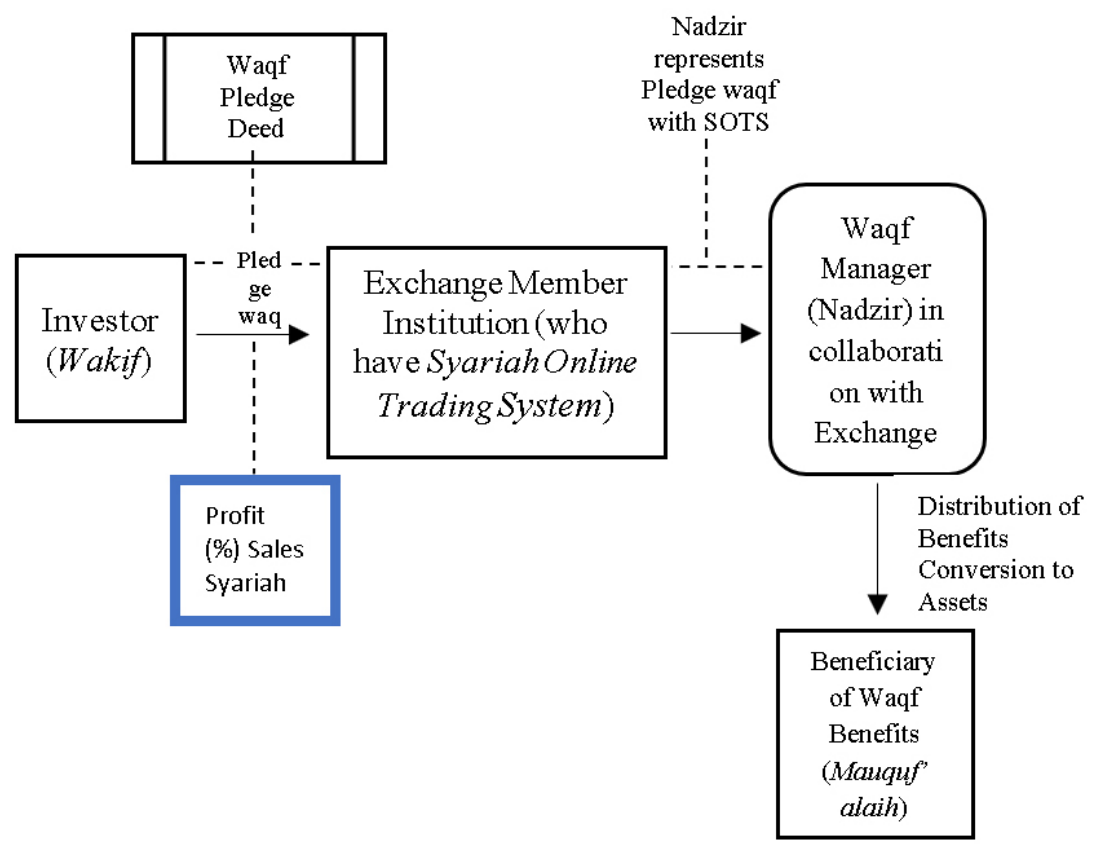

Figure 1. The First Model of Application of Stock Waqf

Source: Hogan (2016) processed

While the application of the second model, Islamic shares purchased by investors are used as a source of waqf, in other words, those that are submitted for waqf are the objects of Islamic shares, not from the benefits of Islamic shares like the application of the first model. The mechanism is the sharia shares that want to be donated to be deposited to the investment management institution, from which the management generates profits which are then deposited to the waqf management institution. The waqf management institution (Nadzir) is responsible for converting into productive assets as well as physical assets that are socially useful, in the form of mosques and schools. It is important to be underlined that the waqf manager cannot change sharia shares that have been donated without the permission of the waqf giver; this is stated in the waqf agreement or pledge. The following is a scheme for implementing the second model of stock waqf: 


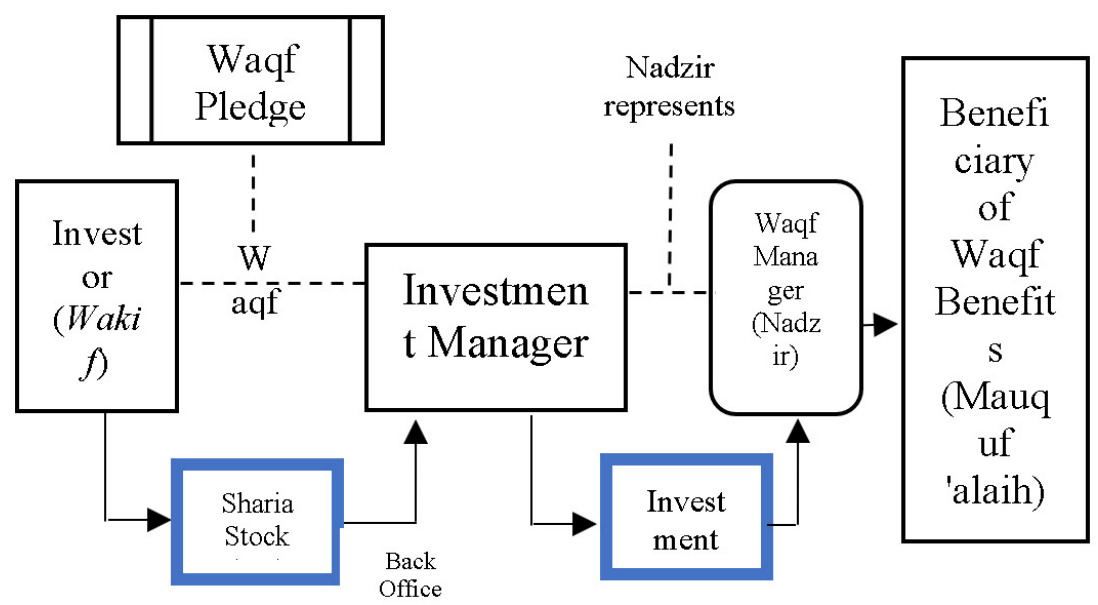

Figure 2. The Second Model of Application of Stock Waqf

The general provisions regarding share waqf, among others (Hogan, 2016):

a. Investors who will do stock waqf can only have sharia stock accounts and transact through the sharia online trading system

b. Exchange members who facilitate only Exchange Members who have the sharia online trading system (SOTS)

c. The object of waqf may only be shares registered in the list of sharia securities

d. Investors can submit sharia shares to the waqf manager (nadzir) collectively through the SOTS Exchange Member (integrated) or do it independently according to the investor's choice.

e. Opportunities and Challenges of Stock Waqf in Indonesia Share waqf has an ample opportunity in line with the increasing number of Sharia stock investors each year (Hogan, 2016) 
Table 1. Opportunities and Challenges of Stock Waqf in Indonesia

\begin{tabular}{|c|c|c|}
\hline & Opportunities & Challenges \\
\hline \multirow[t]{5}{*}{1} & $\begin{array}{l}\text { Increase in the Number of Investors in } \\
\text { Indonesia in the last four years }(2016 \\
\text { to 2020) }\end{array}$ & $\begin{array}{l}\text { Lack of literacy and community } \\
\text { participation in waqf }\end{array}$ \\
\hline & $\begin{array}{l}\text { There is room for growth in the growing } \\
\text { Sharia Capital Market in Indonesia, } \\
\text { including: }\end{array}$ & $\begin{array}{l}\text { There is still limited knowledge } \\
2 \text { and public awareness about waqf, } \\
\text { especially cash waqf and cash waqf }\end{array}$ \\
\hline & $\begin{array}{l}\text { A significant increase in the } \\
\text { a. growth of investors in Islamic } \\
\text { stocks }\end{array}$ & $\begin{array}{l}\text { The quality and quantity of human } \\
3 \text { resources for waqf managers is still } \\
\text { low, especially regarding stocks }\end{array}$ \\
\hline & $\begin{array}{l}\text { The dominance of Islamic stocks } \\
\text { in Indonesia }\end{array}$ & \\
\hline & $\begin{array}{l}\text { Integrated Sharia Investment in } \\
\text { c. the capital market with Islamic } \\
\text { Philanthropy }\end{array}$ & \\
\hline \multirow[t]{4}{*}{2} & $\begin{array}{l}\text { The existence of a comprehensive } \\
\text { Islamic Capital Market education } \\
\text { facility involving various } \\
\text { community networks in society }\end{array}$ & \\
\hline & $\begin{array}{l}\text { The first capital market in the } \\
\text { e. world to develop the Shariah } \\
\text { Online Trading System (SOTS) }\end{array}$ & \\
\hline & $\begin{array}{l}\text { To be the only capital market in the } \\
\text { f. world that has a particular Fatwa } \\
\text { on Islamic stock transactions }\end{array}$ & \\
\hline & $\begin{array}{l}\text { Has the largest number of } \\
\text { securities companies that develop } \\
\text { g. Islamic trading systems or Islamic } \\
\text { Windows Securities Companies in } \\
\text { the world }\end{array}$ & \\
\hline
\end{tabular}

When it comes to opportunities regarding share waqf, Indonesia has enormous potential, considering that the majority of Indonesia's population is Muslim with a total population of 207.6 million (World Bank, 2019). Meanwhile, the number of investors in Indonesia has also increased, based on data from KSEI (in Kontan 2020). an increase in the number of Indonesian capital market investors as of July 2020 recorded at PT Kustodian Sentral Efek Indonesia (KSEI) reached 3.02 million investors or grew $17.8 \%$ compared to the end of 2019 which was only 2.48 
million investors. This number increased significantly by 3.4 times compared to the number of investors in 2016, which was recorded at only 894,000 investors. Of the total, $42 \%$ of them are stock investors; the rest is divided into several between mutual fund and bond investors.

The opportunity to share waqf in Indonesia is enormous in line with the increasing room for growth in the Islamic Capital Market in Indonesia. On September 14, 2020, the Islamic Capital Market again won The Best Islamic Capital Market at the 2020 Global Islamic Finance Awards (GIFA). The award was received virtually and broadcast live from Islamabad, Pakistan at the Online Awards Ceremony (OAC) of the 10th Global Islamic Finance Awards (GIFA). This award is the second time the IDX received an award in 2019 as The Best Islamic Capital Market, which is the highest award category in the global Islamic Capital Market industry. Besides, in previous years, the IDX has received an award as The Best Supporting Institution for Islamic Finance of the Year 2016, 2017 \& 2018 and also an award as The Best Emerging Islamic Capital Market of the Year 2018 (IDX, 2020).

Based on IDX data (2020), The Indonesia Stock Exchange has succeeded in providing consistent growth and development of the Islamic Capital Market in Indonesia in the last nine years. Various initiatives and development activities are carried out with stakeholders, not only efforts to improve but also to maintain compliance with sharia principles which are manifested in several achievements, including:

a. The growth of Sharia Stock Investors in the last four years has increased significantly, such as the number of Islamic stock investors in Indonesia has increased by $536 \%$. As of August 2020, Islamic stock investors have reached 78,199 investors or around $5.9 \%$ of the total investors in Indonesian stocks.

b. Growing and dominating the Islamic stock market in Indonesia. The data shows that as of August 2020 the percentage of the total number of Islamic shares is $63 \%$ of the total shares listed on the IDX, the capitalization of the Islamic stock market is $50 \%$, the volume of Islamic stock 
trading is $65 \%$, the frequency of Islamic stock trading is $68 \%$, and the value of Islamic stock trading transactions is equal to $52 \%$ of the total share trading on the IDX.

c. The Indonesian Sharia Capital Market has innovated and is the only one in the world that has the most comprehensive products and integrates Islamic investment in the capital market with Islamic philanthropy. Not only has investment products; Share waqf, share zakat, share alms and sukuk waqf, the Indonesian Sharia Capital Market also has waqf sukuk, which is the first waqf sukuk in the world.

d. The IDX continues to innovate the Islamic Capital Market. One of them is by providing virtual educational facilities, and having an integrated literacy and inclusion activity platform called Sharia Investment Week (SIW). Not only that, IDX has succeeded in developing the concept of Islamic Capital Market education by integrating and involving various community networks in society, from student communities, homemakers, professionals to preachers and pesantren (Islamic Boarding School) networks.

e. The IDX is the first Stock Exchange in the world to develop the Shariah Online Trading System (SOTS). This platform is an online transaction system that complies with sharia principles that integrate end to end, starting from opening services for sharia stock account to Exchange Members providing SOTS, securities settlement process up to Customer Fund Account (RDN) facility at a Sharia Bank.

f. The Indonesian Sharia Capital Market is the only capital market in the world that has a particular fatwa related to sharia stock transactions on the Stock Exchange, namely the MUI DSN Fatwa No. securities custody at KSEI, namely DSN MUI fatwa No. 124 concerning Application of Sharia Principles in the Implementation of Securities Depository Services and Transaction Settlement Services and Integrated Investment Infrastructure Management.

g. The Indonesian Sharia Capital Market has securities companies that develop the largest Islamic trading system or Islamic Windows Securities Companies in the world. 
Currently, there are 18 Exchange Members (AB) who have developed a sharia online trading system (SOTS), namely; PT Indopremier Sekuritas, PT Mirae Sekuritas, PT BNI Sekuritas, PT Trimegah Sekuritas, PT Panin Sekuritas, PT Mandiri Sekuritas, PT Phintraco Sekuritas, PT SucorInvest Sekuritas, PT First Asia Capital Sekuritas, PT MNC Sekuritas, PT Henan Putihrai Sekuritas, PT Phillip Sekuritas, PT RHB Sekuritas, PT Samuel Sekuritas, PT Maybank Sekuritas, PT OSO Sekuritas Indonesia, PT Kresna Sekuritas, and PT Danareksa Sekuritas.

In the future implementation of the share waqf program in Indonesia face various challenges that must be resolved. These challenges include the lack of literacy and community participation in waqf, based on the survey results of the Waqf Literacy Index (ILW) as follows:

\section{National Waqf Literacy Index Value}

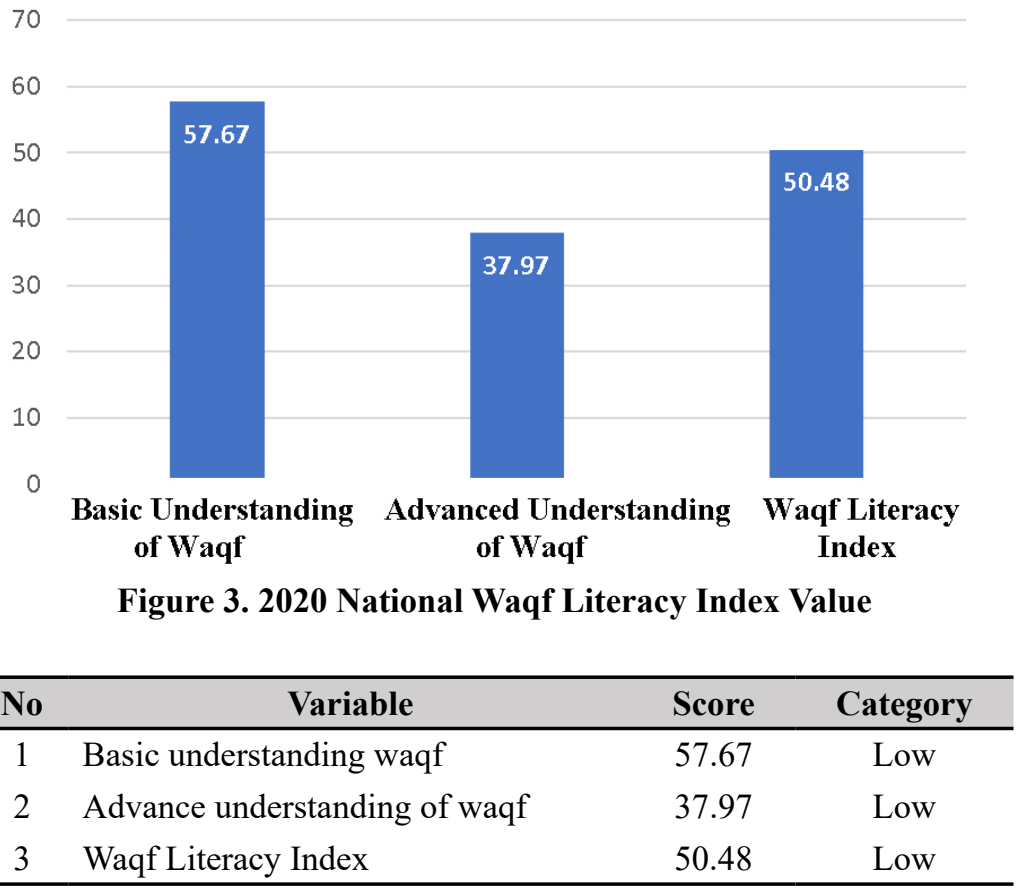


Nationally, the overall Waqf Literacy Index score gets a score of 50.48 or is included in the low category, which consists of the Basic Waqf Understanding Literacy Value of 57.67 and the Advanced Waqf Understanding Literacy Value of 37.97 (Badan Wakaf Indonesia, 2020). Plus the limited knowledge and public awareness of waqf, especially cash waqf and cash waqf (Komite Nasional Keuangan Syariah, 2018).

The low competence, professionalism and quantity of human resources for waqf managers has its certain challenge. Therefore it is necessary to increase competence both technically and managerially for nadzir or waqf managers (Komite Nasional Keuangan Syariah, 2018). During the Waqf Study Forum held by Badan Wakaf Indonesia (BWI), Muhammad Nuh (in Sharianews 2019) said that "The challenge of nadzir affairs is extraordinary, if we are currently discussing in the context of stock waqf, then the nazir must also know about shares". BWI's challenge as the top leader of waqf regulation is expected to be able to know about share waqf and learn about shares, besides that BWI is expected to be able to organize training or training for waqf managers (nadzir) so that nadzirs have an excellent understanding especially regarding share waqf.

\section{CONCLUSION}

Stock waqf has a great opportunity in Indonesia, considering a large number of Indonesians who are predominantly Muslim and referring to the increase in the number of Sharia stock investors in the Islamic Capital Market. The Indonesian Sharia Capital Market has innovated and is the only one in the world that has the most comprehensive product and integrated Islamic investment in the capital market with Islamic philanthropy. However, the implementation of the share waqf program in Indonesia in the future face various challenges that must be resolved with the aim that the share waqf can develop in Indonesia. 


\section{REFERENCES}

BADAN WAKAF INDONESIA. (2020). LAPORAN HASIL SURVEY INDEKS LITERASI WAKAF 2020. 1, 7-8.

DSN-MUI. (2011). Fatwa Dewan Syariah Nasional No. 80/DSNMUI/III/2011. Retrieved from Fatwa DSN-MUI: https:// www.syariahsaham.com/p/fatwa-dsn-mui.html

Febriandika, N. R. (2020). The effect of distributive justice, procedural justice of compensation and emotional intelligence on affective commitments. Jurnal Ilmiah Ekonomi Islam, 6(1), 34-41.

Febriandika, N. R., \& Hakimi, F. (2020). Analisis kesesuaian syariah electronic money pada bank penerbit uang elektronik di indonesia. An-Nisbah: Jurnal Ekonomi Syariah, 7(1), 213-249.

Febriandika, N. R., Millatina, A. N., \& Herianingrum, S. (2020). Customer e-loyalty of muslim millennials in Indonesia: Integrated model of trust, user experience and branding in e-commerce webstore. In Proceedings of the 2020 11th International Conference on E-Education, E-Business, E-Management, and E-Learning (pp. 369-376).

Hadi, A. A. (2017). Fikih muamalah kontemporer. Depok: Rajawali Pers.

Hogan, N. (2016). Wakaf saham, alternatif model wakaf produktif. Retrieved October 25, 2020, from http://www. ekonomisyariah.org/5683/wakaf-saham-alternatif-modelwakaf-produktif/

IDX. (2019). Press Release No 075/BEI.SPR/11-2019: Tahun Ini Jumlah Investor Baru BEI Lampaui Capaian Tahun Lalu. Retrieved October 24, 2020, from https://www.idx.co.id/ berita/press-release-detail/?emitenCode $=1183$

IDX. (2020). Press Release No: 082/BEI.SPR/09-2020: Penghargaan Internasional sebagai The Best Islamic Capital Market kembali Diraih BEI pada GIFA 2020. Retrieved October 28, 2020, from https://www.idx.co.id/berita/pressrelease-detail $/$ emitenCode $=1376$

Indah Yuliana, S. P. (2019). Model penerapan dan potensi 
wakaf saham di Indonesia. Jurnal Perspektif Ekonomi Darussalam, 227-239.

Investasi Kontan. (2020). Jumlah investor di pasar modal sudah capai 3,02 juta investor per Juli 2020. Retrieved October 28, 2020, from https://investasi.kontan.co.id/news/jumlahinvestor-di-pasar-modal-sudah-capai-302-juta-investorper-juli-2020

Komite Nasional Keuangan Syariah. (2018). Masterplan Ekonomi Syariah Indonesia 2019-2024. Kementerian Perencanaan Pembangunan Nasional/Badan Perencanaan Pembangunan Nasional, 1-443.

Majelis Ulama Indonesia. (2002). Keputusan fatwa komisi fatwa majelis ulama indonesia tentang wakaf uang. Jakarta.

Modul SPM. (2018). Jakarta: Bursa Efek Indonesia.

Muzarie, M. (2010). Hukum perwakafan dan implikasinya terhadap kesejahteraan masyarakat: implementasi wakaf di Pondok Modern Darussalam Gontor. Jakarta: Kementerian Agama RI.

Najiyah, F., \& Febriandika, N. R. (2019). The role of government in the zakat management: the implementation of a centralized and decentralized approach (Comparative Study in Indonesia and Malaysia). In 2018 International Conference on Islamic Economics and Business (ICONIES 2018). Atlantis Press.

Paksi, G. M., Manzilati, A., \& Ekawaty, M. (2018). Kajian hukum dan implementasi wakaf harta bergerak Di Indonesia: Wakaf uang dan saham. ISLAMICONOMIC: Jurnal Ekonomi Islam, 9(2), 173-190. https://doi.org/10.32678/ijei.v9i2.94

Rozalinda. (2017). Fikih ekonomi syariah: Prinsip dan implementasinya pada sektor keuangan Syariah. Jakarta: Rajawali Pers.

Sharia News. (2019). BWI ungkap tantangan wakaf saham bagi nazir. Retrieved October 29, 2020, from https://sharianews. com/posts/bwi-ungkap-tantangan-wakaf-saham-bagi-nazir

Wakaf Al Azhar. (2020). Wakaf saham. Retrieved October 25, 2020, from http://wakafalazhar.com/ptta-portfolio/wakaf- 
Journal of Islamic Economic Laws-January, Vol. 4, No. 1, 2021

saham/

World Bank. (2019). Population, total-Indonesia. Retrieved October 24, 2020, from https://data.worldbank.org/ indicator/SP.POP.TOTL?contextual=max\&locations=ID 